\title{
Trends in the development of technical level of the specialized flax harvesting machinery
}

\author{
Aleksandr Lavrov ${ }^{1, *}$, Maksim Moskovskiy ${ }^{1}$, Andrey Boiko $^{2}$, Elena Malaya ${ }^{2}$ and Hoang Ngia \\ Dat $^{3}$ \\ ${ }^{1}$ Federal Scientific Agro-Engineering Center VIM, 1 Institutsky proezd, 5, Moscow, 109428, Russia. \\ ${ }^{2}$ Don State Technical University, Gagarin Square, 1, Rostov-on-Don, 344000, Russia. \\ ${ }^{3}$ Hanoi University of Agriculture, Hanoi, Vietnam.
}

\begin{abstract}
Production of domestic specialized flax harvesting machinery has almost completely stopped in Russia, and the technical level of available fleet machines is significantly concedes to foreign models in many indicators. The main indicators of the technical level have been predicted based on the analysis of the construction development of flax harvesting machine, main directions and achievements in agricultural machinery construction and related areas of equipment. Application of flax harvesting machine with this technical level will significantly improve energy efficiency in flax production.
\end{abstract}

\section{Introduction}

The technical level of flax harvesters and flax-pulling machine is one of the main factors that determine their competitiveness and consumer qualities. Domestic flax harvesting machinery mainly meets the requirements of Russian machine technology in functionality capacity, but it concedes on reliability, fuel efficiency, operator comfort conditions, level of automation and environmental friendliness.

The fleet of flax harvesting machine is replenished by foreign models, which have a higher technical level compared to domestic ones. The most promising foreign models are selfpropelled, the power of this models is in the range of 150-245 hp., technical solutions are implemented in their construction that contribute to improving technical and economic indicators. They become more compact and maneuverable, and thanks to their modern design they offer improved visibility.

Table 1 shows the ranges of changes in indicators of the technical level of domestic and foreign flax harvesting equipment presented on the Russian market.

\footnotetext{
* Corresponding author: tomasss1086@mail.ru
} 
Table 1. Main indicators of the technical level of flax harvesters and flax pickers (average value, in brackets - the range of change)

\begin{tabular}{|l|c|c|}
\hline \multicolumn{1}{|c|}{ Indicators } & Domestic & Foreign \\
\hline $\begin{array}{l}\text { Net productivity, ha/ } \mathrm{h} \text { (Flax harvester } \\
\text { / flax-pulling machine) }\end{array}$ & $1,1-1,5 / 1,4-3,5$ & none/ 3,5-4,6 \\
\hline Specific fuel consumption, g / kW * $\mathrm{h}$ & $224-238$ & $209-245$ \\
\hline Power, h.p. & $80-109$ & $150-245$ \\
\hline Capture width, $\mathrm{m}$ & $1,5-2,6$ & $1,5-2,6$ \\
\hline Working speed, km / h & $7-12$ & $15-18$ \\
\hline Transport speed, km / h & $20-25$ & $25-37$ \\
\hline Weight, kg & $5400-6950$ & $8500-10450$ \\
\hline Energy saturation, $\mathrm{kW} / \mathrm{kN}$ & $0,9-1,1$ & $1,35-1,79$ \\
\hline Automation category & $\mathrm{C}-\mathrm{B}$ & $\mathrm{B}$ \\
\hline Turning radius, $\mathrm{m}$ & $4,2-7,5$ & $5,5-8,6$ \\
\hline Noise level in the cabine, $\mathrm{dBA}$ & $80-85$ & $70-75$ \\
\hline Environmental requirements & Euro-1-Euro-3 & Euro-4 \\
\hline Availability coeficient, $\%$ & $0,98-0,99$ & $0,97-0,98$ \\
\hline
\end{tabular}

The aim of the research is classification of flax harvesters and flax-pulling machine by changing technological properties, as well as to predict the main indicators of their technical level.

\section{Materials and methods}

It is proposed to single out separately generations characterized by a significant improvement in technological properties based on the analysis of the development of the construction of flax harvesting machinery [1,2].

The first generation is the formation of construction of harvesters, replacement of manual labor with mechanized;

The second generation is increasing operating speeds and energy saturation by increasing engine power, increasing net performance;

The third generation is the formation of self-propelled harvesters, improving the quality of harvesting;

The fourth generation is automation and robotization of work processes, increased shift productivity;

The fifth generation is reduced structural weight, increased energy efficiency (cost per unit of useful work) and environmental safety.

The analysis of the world production of agricultural machinery makes it possible to identify the following directions of development of the technical level of flax harvesters and toplifting machines $[3,4]$ :

- an increase in the number of models of produced flax harvesting machines;

- growth in the capacity of produced self-propelled flax harvesting machines;

- reducing losses and improving the quality of products;

- improvement of engines, fuel equipment, filtration and air release systems;

- consideration of environmental requirements in the design of machines;

- the use of alternative energy sources;

- the use of an electric drive for the implementation of the technological process;

- the use of adaptive running systems;

- expanding the use of electronic equipment and automation tools for monitoring and controlling operations and processes;

- introduction of intelligent systems; 
- increasing the efficiency of security systems;

- expanding the use of plastics and new materials;

- creation of comfortable and safe working conditions;

- introduction of modern finishing and painting methods;

- reduction in structural weight;

- increasing interproject unification;

- block-modular and modular-modular construction.

\section{Results and discussion}

Tables 2, 3 show the technical characteristics of each generation of flax harvesters and flax pickers, where Mop is weight of the machine ion operation, Mm- weight of machine. In these Table it were presented flex harvester of domestic and foreign production, where:

LK-7 is flex harvester type 7, tractor-hitched;

LK-5 is flex harvester type 5, tractor-hitched;

LKB-4T is flex harvester type 4 modernized, tractor-hitched;

LK-4A is flex harvester type 4, tractor-hitched;

LS35 is self-propelled flex harvester;

LT-7 is flex-pulling machine type 7, tractor-hitched;

TLN-1,5 is flex-pulling equipment, tractor-hitched;

LT-4 is flex-pulling machine type 4, tractor-hitched;

MTL-1,5 is flex-pulling equipment, tractor-hitched;

TLP-1,5K is flex-pulling machine type 4, tractor-hitched;

LTS-1,65 is flex-pulling machine, self-propelled with capture width 1,65 m;

LTS-2 is flex-pulling machine, self-propelled with capture width $2,0 \mathrm{~m}$;

LTD-220 is flex-pulling machine, self-propelled with capture width 2,20 m;

UnionGX220 is flex-pulling machine, self-propelled;

Table 2. Technical characteristics of flax harvesters.

\begin{tabular}{|c|c|c|c|c|c|c|c|c|}
\hline $\begin{array}{l}\text { Gener } \\
\text { ation }\end{array}$ & Model & $\begin{array}{c}\text { Work } \\
\text { ing } \\
\text { speed } \\
\text { km/h }\end{array}$ & $\begin{array}{l}\text { Cap } \\
\text { ture } \\
\text { widt } \\
\text { h, m }\end{array}$ & $\begin{array}{c}\text { Productivity } \\
\text { of pure time, } \\
\text { ha/h }\end{array}$ & $\begin{array}{c}\text { Pow } \\
\text { er, } \\
\text { kWt }\end{array}$ & $\begin{array}{l}\text { Weight, kg } \\
\left(M_{o p}+M_{m}\right)\end{array}$ & $\begin{array}{c}\text { Energy } \\
\text { saturati } \\
\text { on, kW / } \\
\text { kN }\end{array}$ & $\begin{array}{c}\text { Catego } \\
\text { ry of } \\
\text { autom } \\
\text { ation }\end{array}$ \\
\hline \multirow{2}{*}{$\begin{array}{l}\text { The } \\
\text { first }\end{array}$} & LK-7 & $3,5-5$ & 2,66 & 1,1 & 42 & $3700+2570$ & 0,67 & $\mathrm{D}$ \\
\hline & LK-5 & $3,5-5$ & 1,9 & 0,7 & 42 & $3700+2200$ & 0,7 & $\mathrm{D}$ \\
\hline \multirow[t]{2}{*}{$\begin{array}{l}\text { The } \\
\text { second }\end{array}$} & $\begin{array}{c}\text { LKB- } \\
4 \mathrm{~T}\end{array}$ & $7-10$ & 1,52 & 1,05 & 62 & $3800+1850$ & 1,09 & D \\
\hline & LK-4A & $9-10$ & 1,52 & 1 & 62 & $3800+2100$ & 0,9 & $\mathrm{D}$ \\
\hline $\begin{array}{l}\text { The } \\
\text { third }\end{array}$ & LS35 & $9-10$ & 1,65 & 1,1 & 77 & 6950 & 1,1 & $\mathrm{C}$ \\
\hline $\begin{array}{l}\text { The } \\
\text { fourth }\end{array}$ & $\begin{array}{c}\text { analogu } \\
\text { e LS35 }\end{array}$ & $9-10$ & 1,65 & $\begin{array}{c}1,15 \\
\text { (changeable) }\end{array}$ & 77 & 6950 & 1,1 & B \\
\hline $\begin{array}{l}\text { The } \\
\text { fifth } \\
\text { (foreca } \\
\text { st) }\end{array}$ & $\begin{array}{l}\text { analogu } \\
\text { e LS35 }\end{array}$ & $9-10$ & 1,65 & $\begin{array}{c}1,15 \\
\text { (changeable) }\end{array}$ & 77 & 4500 & 1,7 & B (A) \\
\hline
\end{tabular}


Table 3. Technical characteristics of flax picking machines

\begin{tabular}{|c|c|c|c|c|c|c|c|c|}
\hline $\begin{array}{l}\text { Gene } \\
\text { ratio } \\
\text { n }\end{array}$ & Model & $\begin{array}{l}\text { Wor } \\
\text { king } \\
\text { spee } \\
\text { d, } \\
\text { km/ } \\
\text { h }\end{array}$ & $\begin{array}{c}\text { Cap } \\
\text { ture } \\
\text { wid } \\
\text { th, } \\
\text { m }\end{array}$ & $\begin{array}{c}\text { Producti } \\
\text { vity of } \\
\text { pure } \\
\text { time, } \\
\text { ha/h }\end{array}$ & $\begin{array}{c}\text { Powe } \\
\text { r, } \\
\text { kWt }\end{array}$ & $\begin{array}{l}\text { Weight, kg } \\
\left(M_{\text {op }}+M_{m}\right)\end{array}$ & $\begin{array}{c}\text { Energy } \\
\text { saturati } \\
\text { on, kW } \\
\text { / kN }\end{array}$ & $\begin{array}{l}\text { Categor } \\
\text { y of } \\
\text { automa } \\
\text { tion }\end{array}$ \\
\hline $\begin{array}{l}\text { The } \\
\text { first }\end{array}$ & LT-7 & $3,5-5$ & 2,66 & $0,9-1,3$ & 17 & $2600+1400$ & 0,4 & $\mathrm{D}$ \\
\hline \multirow{4}{*}{$\begin{array}{l}\text { The } \\
\text { secon } \\
\text { d }\end{array}$} & $\begin{array}{l}\text { TLN- } \\
1,5\end{array}$ & $5-8$ & 1,5 & $0,75-1,2$ & 14 & $1560+260$ & 0,77 & $\mathrm{D}$ \\
\hline & LT-4 & $6-9$ & 1,52 & $0,9-1,35$ & 42 & $3700+1500$ & 0,8 & $\mathrm{D}$ \\
\hline & $\begin{array}{l}\text { MTL- } \\
1,5\end{array}$ & $\begin{array}{c}10 \\
(7,2)\end{array}$ & 1,5 & 1,01 & 38 & $2600+460$ & 1,2 & $\mathrm{D}$ \\
\hline & $\begin{array}{l}\text { TLP- } \\
1,5 \mathrm{~K}\end{array}$ & 18 & 1,5 & 1,04 & 62 & $3800+1380$ & 1,17 & $\mathrm{D}$ \\
\hline \multirow[t]{3}{*}{$\begin{array}{l}\text { The } \\
\text { third }\end{array}$} & $\begin{array}{l}\text { LTS- } \\
1,65 \\
\end{array}$ & $5-12$ & 1,65 & 1,4 & 80 & 4500 & 1,75 & $\mathrm{C}$ \\
\hline & LTS-2 & 15 & 2 & $0,8-1,6$ & 109 & 6800 & 1,6 & $\mathrm{C}$ \\
\hline & $\begin{array}{l}\text { LTD- } \\
220 \\
\end{array}$ & 18 & 2,6 & 3,5 & 80 & 5400 & 1,5 & $\mathrm{C}$ \\
\hline $\begin{array}{l}\text { The } \\
\text { fourth }\end{array}$ & $\begin{array}{c}\text { Union } \\
\text { GX220 }\end{array}$ & 18 & 2,6 & 4,6 & 188 & 10460 & 1,79 & B \\
\hline $\begin{array}{l}\text { The } \\
\text { fifth } \\
\text { (forec } \\
\text { ast) }\end{array}$ & $\begin{array}{c}\text { analog } \\
\text { ue } \\
\text { LTD- } \\
220 \\
\end{array}$ & $\begin{array}{l}18- \\
20\end{array}$ & 2,6 & $\begin{array}{c}3,5 \\
\text { (changea } \\
\text { ble) }\end{array}$ & 90 & 4500 & 2 & $\mathrm{~B}(\mathrm{~A})$ \\
\hline
\end{tabular}

Based on the development trends of flax harvesters and flax pickers, the forecast of flax production technologies, advances in science and technology, the main indicators of flax pickers and flax harvesters of the fifth generation are proposed (Table 4).

Table 4. Main indicators of technical requirements for flax harvesters and flax pickers

\begin{tabular}{|l|c|c|}
\hline \multicolumn{1}{|c|}{ Indicators } & Flax harvesters & Flex-pulling machine \\
\hline Operating Power, $\mathrm{kWt}$ & $80-100$ & $90-110$ \\
\hline Capture width, $\mathrm{m}$ & 1,65 & 2,6 \\
\hline Working speed, $\mathrm{km} / \mathrm{h}$ & $10-12$ & $18-20$ \\
\hline Transport speed, $\mathrm{km} / \mathrm{h}$ & $35-40$ & $35-40$ \\
\hline Productivity of pure time, $\mathrm{ha} / \mathrm{h}$ & 1,7 & 4,6 \\
\hline Changeable productivity, ha/h & 1,15 & 3,5 \\
\hline Coeficient of changeable, $\%$ & $0,7-0,8$ & $0,75-0,85$ \\
\hline Weight, kg & 4500 & 4500 \\
\hline Energy saturation, $\mathrm{kW} / \mathrm{kN}$ & $1,7-2,2$ & $2,0-2,4$ \\
\hline Category of autimation & $\mathrm{A}$ & $\mathrm{A}$ \\
\hline Environmental requirements & EURO-4 & E EURO-48po-4 \\
\hline Maximum soil pressure, $\mathrm{kN}$ & $80-100$ & $70-100$ \\
\hline Noise level in the cabine, $\mathrm{dBA}$ & $70-72$ & $0,98-0,99$ \\
\hline Availability coeficient, $\%$ & $0,98-0,99$ & \\
\hline
\end{tabular}




\section{Conclusions}

The use of flax harvesters and flax-picking machines with the proposed parameters will reduce the total specific energy consumption of a unit of useful work by 1.4-1.6 times, environmental safety, competitiveness, and will also significantly increase the level of marketability and profitability of flax fiber production in Russia.

\section{Reference}

1. Lavrov A.V., Shevtsov V.G., Zubina V.A. Assessment of the impact of technical level indicators on the productivity of agricultural tractors, In the collection: Collection of articles on the results of the II International Scientific and Practical Conference "Goryachkin Readings" dedicated to the 150th anniversary of the birth of Academician V.P. Goryachkina. p. 333-336 (2019).

2. Godzhaev Z.A., Lavrov A.V., Shevtsov V.G., Zubina V.A. On the choice of the technological direction of the development of the system of agricultural mobile energy facilities, Izvestia of the Moscow State Technical University MAMI. No. 1 (43). p. 3541. (2020)

3. Izmailov A., Shevtsov V., Lavrov A., Godzhaev Z., Zubina V., Andreeva A. Evaluation of the technical level of modern agricultural tractors represented in the Russian market, SAE Technical Papers. T. 2018-April, (2018).

4. Izmailov A.Yu., Kryazhkov V.M., Antyshev N.M., Shevtsov V.G., The concept of modernization of the Russian agricultural tractor fleet for the period until 2020, M .: VIM, 87 p. (2013). 